\title{
Dataset of occurrences and ecological traits of amphibians from Upper Paraguay River Basin, central South America
}

\author{
Matheus Oliveira Neves', Hugo Cabral2,3, Mariana Pedrozo ${ }^{4}$, \\ Vanda Lucia Ferreira ${ }^{5}$, Mário Ribeiro Moura ${ }^{6}$, Diego José Santana ${ }^{5}$
}

I Programa de Pós-Graduação em Ecologia e Conservação, Instituto de Biociências, Universidade Federal de Mato Grosso do Sul. Cidade Universitária, Campo Grande, MS, 79070-900, Brazil 2 Programa de PósGraduação em Biologia Animal, Universidade Estadual Paulista, Campus São José do Rio Preto. São José do Rio Preto, SP, 15054-000, Brazil 3 Instituto de Investigación Biológica del Paraguay. Del Escudo 1607, Asunción, Paraguay 4 Programa de Pós-Graduação em Biologia Animal, Instituto de Biociências, Universidade Federal de Mato Grosso do Sul. Cidade Universitária, Campo Grande, MS, 79070-900, Brazil 5 Instituto de Biociências, Universidade Federal de Mato Grosso do Sul. Cidade Universitária, Campo Grande, MS, 79070-900, Brazil 6 Departmento de Ciências Biológicas, Universidade Federal da Paraíba. Areia, PB, 58397-000, Brazil

Corresponding author: Matheus O. Neves (nevesmo@yahoo.com.br)

Academic editor: W. Magnusson | Received 14 May 2020 | Accepted 28 July 2020 | Published 2 September 2020

http://zoobank.org/89B547A7-056E-44D3-8CC2-3E12FF05827E

Citation: Neves MO, Cabral H, Pedrozo M, Ferreira VL, Moura MR, Santana DJ (2020) Dataset of occurrences and ecological traits of amphibians from Upper Paraguay River Basin, central South America. Nature Conservation 41: 7189. https://doi.org/10.3897/natureconservation.41.54265

\begin{abstract}
There are many gaps in our biodiversity knowledge, especially in highly diverse regions such as the Neotropics. Basic information on species occurrence and traits are scattered throughout different literature sources, which makes it difficult to access data and ultimately delays advances in ecology, evolution, and conservation biology. We provide species occurrence and trait data for amphibian species in the Upper Paraguay River Basin, central South America. The compiled information is made available through two different datasets that hold (i) $17 \mathrm{~K}$ species occurrence records and (ii) 30 species-level traits for 113 amphibian species. The first dataset includes the species occurrence records and informs specimen id, collection of housing, locality, geographical coordinates, geographic accuracy, collection date, and collector name. The second dataset covers species-level attributes on morphometry, diet, activity, habitat, and breeding strategy. These datasets improve accessibility to spatial and trait data for amphibian species in the Pantanal ecoregion, one of the largest wetlands on Earth.
\end{abstract}

Copyright Matheus Oliveira Neves et al. This is an open access article distributed under the terms of the Creative Commons Attribution License (CC BY 4.0), which permits unrestricted use, distribution, and reproduction in any medium, provided the original author and source are credited. 


\section{Keywords}

Anura, Datapaper, Gymnophiona, life history traits, Pantanal floodplain, wetland

\section{Introduction}

The availability of species occurrences data is not uniform throughout the Earth and many gaps exist, especially in megadiverse regions such as the tropics (Collen et al. 2008, Meyer 2016). Georeferenced information is imperative for many basic and applied ecology fields (Whittaker et al. 2005), such as biogeography (Lomolino 2004, Silva et al. 2018), evolutionary biology (Holt 2003), and conservation planning (Whittaker et al. 2005, Chen et al. 2017). Although efforts to reduce knowledge gaps in species distribution have increased over the years, knowledge on species distribution is still incomplete (Lomolino et al. 2016). The accumulated occurrence data are not spatially uniform, with on-ground accessibility, economic development, and nature appeal largely affecting the inventory completeness of particular regions (Meyer et al. 2016, Moura et al. 2018). Inter- and intra-country variation in public policy may also add up to reduce the efficacy of initiatives to reduce sampling gaps (Beck et al. 2014, Troudet et al. 2017).

One way to reduce biodiversity knowledge gaps is through improving accessibility and data sharing networks (Chavan and Penev 2011). The Global Biodiversity Information Facility (GBIF), the largest online depository of occurrence records in the world, allows access to data from many natural history collections worldwide (GBIF.org 2019). However, the raw data fed to GBIF may include misidentifications or invalid species names due to outdated taxonomy provided by scientific collections (Beck et al. 2014). For example, it has been found that herbaria collections can hold up to $40 \%$ of Amazonian plant specimens with erroneous identifications (Hopkins 2007). To minimize this problem, researchers have relied on curated data papers (Chavan and Penev 2011). Data papers can also include information on species ecology to extend potential applications (Grimm et al. 2014, Oliveira et al. 2017, Gillings et al. 2019). Ecological traits determine species' ability to persist in a variety of environments and reflect the outcome of ecoevolutionary pressures on species interactions with abiotic and biotic factors (Ingram and Shurin 2009, Swenson and Weiser 2010). Spatial and trait data have been used to improve spatial models (Dubuis et al. 2013, D'Amen et al. 2015, Guisan et al. 2019), forecast community structure and dynamics (Cadotte et al. 2015, Blonder et al. 2018), predict population trends (Lips et al. 2003, Williams et al. 2010, Coulthard et al. 2019), and to understand potential impacts of climate change (Diamond et al. 2011, Foden et al. 2013). In spite of their importance, trait data are also scattered throughout literature, making its use difficult in comparative studies (Grimm et al. 2014).

Among those regions without proper biodiversity knowledge is the Upper Paraguay River Basin (UPRB), in the center of South America and home of the largest 
wetland of the world (Alho et al. 1988, Junk and Wantzen 2004). The UPRB covers the Pantanal ecoregion, which is classified as an UNESCO World Heritage Site since 2000 (UNESCO 2020). It encompasses transition zones among Pantanal and other South American ecoregions, such as Cerrado, Amazonia, Chiquitano Dry Forest, and Dry and Humid Chaco (Olson et al. 2001), across the borders of Brazil, Bolivia, and Paraguay. The confluence of diverse fauna and flora from these different ecoregions is a peculiar characteristic of the UPRB (Silva et al. 2000, Piatti et al. 2019). Because of the spatially varying flooding regimes, many areas in the UPRB show low on-ground accessibility and therefore are still poorly sampled (Uetanabaro et al. 2008, Souza et al. 2017). Amphibian assemblages of some areas within the UPRB are completely unexplored, such as the Pantanal do Paiaguás and Pantanal do Nabileque, Central and South-west of the Pantanal, respectively (Souza et al. 2017), despite punctual efforts to catalogue amphibians in the Pantanal and surroundings. Given the present knowledge, the UPRB is characterized by higher amphibian richness in the surrounding plateaus, and fewer species in the floodplain, but with high abundance (Uetanabaro et al. 2008). Herein we make available more than 17,000 records for 113 amphibian taxa that occur in the basin. Whenever available and for each geographical record, we provide information on the collection of housing, locality, geographical coordinates, geographic accuracy, collection date, and collectors. For each species, we present trait information on the morphometry, diet, activity, habitat, and breeding strategy.

\section{Methods}

\section{Data compilation}

We compiled occurrence records for amphibians in the Upper Paraguay River Basin (UPRB) through specimens available in scientific collections and fieldwork. We visited five collections in Brazil: (i) Coleção Zoológica de Referência da Universidade Federal de Mato Grosso do Sul (ZUFMS-AMP), Campo Grande, Mato Grosso do Sul state; (ii) Coleção Herpetológica da Universidade de Brasília (CHUNB), Brasília, Federal District; (iii) Coleção Zoológica da Universidade Federal de Mato Grosso (ZUFMTAMP), Cuiabá, Mato Grosso state; (iv) Coleção Herpetológica Célio F. B. Haddad, of the Universidade Estadual Paulista (CFBH), Campus of Rio Claro, São Paulo state; and (v) Coleção de Anfíbios do Museu Nacional of the Universidade Federal do Rio de Janeiro (MNRJ), Rio de Janeiro, Rio de Janeiro state. We also verified amphibian specimens deposited at the Colección Herpetológica del Museo de Historia Natural Noel Kempff Mercado (MNKA), Santa Cruz de La Sierra, Santa Cruz Department, Bolivia; and in the Colección Herpetológica del Instituto de Investigación Biológica del Paraguay (IIBT-H), Asunción, Capital District, Paraguay. Fieldwork records were based on ongoing research developed by us and members of the Mapinguari Lab (voucher specimens from such research were housed in the ZUFMS collection). Specimens from fieldwork received the additional label MAP to allow their differentiation from speci- 
mens previously available at the ZUFMS collection. In addition, we gathered information on morphometry, diet, activity, habitat, and breeding strategy for each amphibian species found in the UPRB based on the literature available.

\section{Data description}

Information on spatial and trait data for amphibian species of the Upper Paraguay River Basin (UPRB) is presented as two supplementary tables. Suppl. material 1: Table S1 includes the species occurrence data, whereas the Suppl. material 2: Table S2 contains the species-level trait data. We acknowledge that the spatial occurrence data is subject to taxonomic uncertainty, that is, the difficult of confirming the id of some species based on preserved specimens only. Therefore, for Suppl. material 1: Table S1, we provided 14,900 occurrence records for 89 amphibian species identified at the species-level, and additional 2,189 occurrence records for 24 taxonomic 'entities' of amphibians with taxonomic uncertainty (species identifications including "aff.", "gr.", "cf.", and "sp."). Taxonomy issues for some species are discussed in the session Taxonomy deliberation.

Suppl. material 2: Table 22 is defined at the species-level and therefore not subjected to the taxonomic uncertainty of preserved specimens. The trait data is presented for all 113 amphibian species that occur within the UPRB. References consulted to build the Table S2 are listed in the Suppl. material 2. In the following, we provide details on the fields represented in the two supplementary tables.

\section{Suppl. material 1: Table $S 1$ - Species occurrence records}

Suppl. material 1: Table S1 contains the following fields:

Collection: The acronym of the scientific collection where the specimens are housed. ZUFMS-AMP = Zoological Collection of Reference of the Universidade Federal de Mato Grosso do Sul. CHUNB = Herpetological Collection of the Universidade de Brasília. ZUFMT-AMP = Zoological Collection of the Universidade Federal de Mato Grosso. CFBH = Herpetological Collection Célio F. B. Haddad, Universidade Estadual Paulista. MNRJ = Amphibian Collection of the Museu Nacional, Universidade Federal do Rio de Janeiro. MNKA = Herpetological Collection of the Museo de Historia Natural Noel Kempff Mercado. IIBP-H = Herpetological Collection of the Instituto de Investigación Biológica del Paraguay. MAP = Fieldwork collection of the Mapinguari Lab (which will be housed in ZUFMS after).

Label number: number in the collection in which the specimen is housed. This information was extracted directly from the scientific collection records.

Family/Genus/Id._Level/Epithet/Species: Taxonomic data of the specimen (Family, Genus and Species). The column named "Id._Level" is related to the taxonomic level known ("cf.", "aff.", "gr." or "sp.", see "Taxonomy deliberation" session). If the "Id._Level" column is empty, the specimen was identified at the species level. 
Locality: Name of the locality where the specimen was collected. It might refer to local designations, villages, or other locations below the municipality level. Locality information was extracted from the specimen catalogue available at each scientific collection.

Municipality/Adm_unit/Country: Information on the municipality, administrative unit (state level for Brazil, and department level for Bolivia and Paraguay), and country where the specimen was collected.

Latitude/Longitude: Geographic coordinates of the specimen, in decimal degrees. These data were made available mostly by the collectors. However, for specimens with missing data, we obtained the geographic coordinates of their respective locality via Google Earth Pro.

Geographic_Accuracy: Geographic accuracy of the record indicated by one of the three following levels. (i) "Exact_Location", for records of the exact place where the specimen was captured. (ii) "Nearby_Location", the collector did not provide the geographic coordinates but we obtained it through the locality description. And (iii) "Municipality_Centroid", records with unknown exact or nearby location were georeferenced based on the municipality centroid.

Collection_Day/Collection_Month/Collection_Year: Day, month, and year of the record. Data extracted from the catalogue of specimens available at each scientific collection.

Collector: The name of the collector who made the record, as informed in the catalogue of specimen. Only $37.5 \%$ of the records have this field filled.

\section{Suppl. material 2: Table S2 - Species traits}

Suppl. material 2: Table S2 contains 30 fields distributed in seven general topics: Identification (columns with gray background color), Conservation (brown background color), Morphometry (green background color), Diet (blue background color), Habitat (red background color), Activity period (yellow background color), Breeding strategy (orange background color), and References:

\section{Identification-related fields}

Family/Species/Year_of_description: Taxonomic level for family and species, followed by the year of description for each species.

Number_of_records: Number of georeferenced specimens in Suppl. material 1: Table S1 for each species.

\section{Conservation-related fields}

IUCN: Conservation status as provided by IUCN Red List Category and Criteria (2020) categorized as: Least Concern (LC), Data Deficient (DD), Near Threatened (NT), and Not Evaluated (NE). 
IUCN_Pop: Current population trends as available at IUCN Red List Category and Criteria (2020): stable, unknown, decreasing, increasing, and Not Evaluated (NE).

\section{Morphometry-related fields}

Body_size: Mean Snout-Vent Length (SVL, in millimeters) for males, females, and for the species. In some cases, we found this value only for the species (not for male and female separately). If SVL was available only for males and females, we averaged both values to get the species mean.

Head_length: Mean Head Length (in millimeters) for males, females, and for the species. In some cases, we found this value only for the species (not for male and female separately). If head length was available only for males and females, we averaged both values to get the species mean.

Head_width: Mean Head Width (in millimeters) for males, females, and for the species. In some cases, we found this value only for the species (not for male and female separately). If head width was available only for males and females, we averaged both values to get the species mean.

Reference_Morphometry: References consulted for the morphometry of each species. All references are listed in the Suppl. material 3. Personal Communication were provided directly by us or by other colleagues consulted.

\section{Diet-related fields}

The different levels of prey type were organized in multiple columns, each column indicating the taxonomic group (up to Order, mostly) of the respective prey. See Table 1 for the complete list of preys categories. The Order Hymenoptera was registered into three different fields: "Hymenoptera_Formicidae" informs the percentage of ants among amphibian preys; "Hymenoptera_non_Formicidae" informs the percentage of others group of Hymenoptera, exemption of Formicidae; and "Hymenoptera" for the sum of "Hymenoptera_Formicidae" and "Hymenoptera_non_Formicidae", or when the author of the source provided information on Hymenoptera only. If prey identification was unavailable at the Order level, we used a higher taxonomic rank (e.g., Annelida, Insect_Pupa, Insect_Larvae) to differentiate preys. When two or more prey types belonged to the same higher taxon, but at different ranks, we did not sum those values. For example, Ixodida is an Order of Acari, but in our dataset, we did not add the values of "Ixodida" with those of "Acari" when the author provided these values separately. In each column, the data can be available in two different forms according to the information originally reported: (i) Presence/Absence data (dark blue background color) are classified as 0 (absence) and 1 (presence) if information on the Index of Relative Importance (IRI) was unavailable; and (ii) Percentage of IRI data (\%IRI), the relative contribution of each prey category to the total IRI of each species. In these cases, items that could not be identified (e.g., fragmented bodies and advanced stages of digestion) were referred in the column "Not_ Identified_raw_IRI" and they are not considered for the computation of the \%IRI. 
Table I. Prey categories in the dataset. It includes Phylum, Class and the Prey Category (when available by the reference) and up the taxonomic level of Prey Category identified.

\begin{tabular}{|c|c|}
\hline Phylum/Class/Prey_Category & Taxonomic level of Prey Category \\
\hline \multicolumn{2}{|l|}{ Anellida } \\
\hline Anellida & Phylum \\
\hline \multicolumn{2}{|l|}{ Arthropoda } \\
\hline \multicolumn{2}{|l|}{ Arachnida } \\
\hline Acari & Subclass \\
\hline Ixodida (Acari) & Order \\
\hline Araneae & Order \\
\hline Opiliones & Order \\
\hline Pseudoscorpiones & Order \\
\hline Scorpiones & Order \\
\hline \multicolumn{2}{|l|}{ Chilopoda } \\
\hline Chilopoda & Class \\
\hline Scolopendromorpha & Order \\
\hline \multicolumn{2}{|l|}{ Crustacea } \\
\hline Crustacea & Subphylum \\
\hline \multicolumn{2}{|l|}{ Diplopoda } \\
\hline Diplopoda & Class \\
\hline Spirostreptida & Order \\
\hline \multicolumn{2}{|l|}{ Entognatha } \\
\hline Collembola & Superorder \\
\hline \multicolumn{2}{|l|}{ Insecta } \\
\hline Blattodea & Order \\
\hline Coleoptera & Order \\
\hline Dermaptera & Order \\
\hline Diptera & Order \\
\hline Ephemeroptera & Order \\
\hline Hemiptera & Order \\
\hline Hymenoptera_Formicidae & Order \\
\hline Hymenoptera & Order \\
\hline Hymenoptera_non_Formicidae & Order \\
\hline Insect_Larvae & Class \\
\hline Insect_Pupa & Class \\
\hline Isopoda & Order \\
\hline Isoptera & Order \\
\hline Lepidoptera & Order \\
\hline Mecoptera & Order \\
\hline Odonata & Order \\
\hline Orthoptera & Order \\
\hline Plecoptera & Order \\
\hline Psocoptera & Order \\
\hline Thysanoptera & Order \\
\hline Trichoptera & Order \\
\hline \multicolumn{2}{|l|}{ Malacostraca } \\
\hline Decapoda & Order \\
\hline \multicolumn{2}{|l|}{ Chordata } \\
\hline \multicolumn{2}{|l|}{ Actinopterygii } \\
\hline Synbranchiformes & Order \\
\hline \multicolumn{2}{|l|}{ Amphibia } \\
\hline Anura & Order \\
\hline Gymnophiona & Order \\
\hline
\end{tabular}




\begin{tabular}{|c|c|}
\hline Phylum/Class/Prey_Category & Taxonomic level of Prey Category \\
\hline \multicolumn{2}{|l|}{ Aves } \\
\hline Aves & Class \\
\hline \multicolumn{2}{|l|}{ Mammalia } \\
\hline \multicolumn{2}{|l|}{ Mammals } \\
\hline \multicolumn{2}{|l|}{ Reptilia } \\
\hline \multicolumn{2}{|l|}{ Lizards } \\
\hline \multicolumn{2}{|l|}{ Mollusca } \\
\hline Mollusca & Phylum \\
\hline \multicolumn{2}{|l|}{ Others } \\
\hline Vegetal_material & Kingdom \\
\hline Not_identifield_raw_IRI & \\
\hline
\end{tabular}

Reference_Diet: References consulted for the diet of each species. All references are listed in Suppl. material 3. Personal Communication were provided directly by us or by other colleagues consulted.

\section{Habitat-related fields}

Major Habitat: Vegetational formation where the species is commonly present. We considered three major habitat types: (i) "Open" for species occurring in the Cerrado sensu stricto, grasslands, shrublands, and wetlands; (ii) "Forest" for species occurring in moist broadleaf forest, dry broadleaf forest, and riparian forest; and (iii) "Forest_Open" if the species is present in physiognomies of both major habitat type.

Habitat use: The microhabitat used by the post-metamorphic individuals. We classified microhabitats in four levels: (i) "Aquatic" when the species lives in the water body; (ii) "Arboreal" to species that use shrubs or trees for calling and live; (iii) "Fossorial" for species that lives underground or buried for some period; and (iv) "Terrestrial" for species that lives in the ground. As a note, a same species can use one or more level of habitat use.

Reference_Habitat: References consulted for the habitat of each species. All references are listed in Suppl. material 3. Personal Communication were provided directly by us or by other colleagues consulted.

\section{Activity-related fields}

Seasonality: Seasonal activity of the species was classified as (i) "Dry" when it breeds in the winter (also the dry season in the UPRB); and (ii) "Wet" if it breeds in the summer (wet season in the UPRB). Species that can breed in both seasons were classified as "Dry_Wet".

Habit: Period of activity of the species when it feeds and reproduces. We classified species as (i) "Diurnal" or (ii) "Nocturnal". Species active at both day and night were classified as "Diurnal_Nocturnal". 
Reference_Activity: References consulted for the activity of each species. All references are listed in Suppl. material 3. Personal Communication were provided directly by us or by other colleagues consulted.

\section{Breeding-related fields}

Reproductive_mode: The reproductive mode characteristic of each species. The mode number for anurans follows the description provided by Haddad and Prado (2005) and Wells (2007) for caecilians.

Development: The mode of development after the egg hatching, classified as (i) "Indirect" development when the species has larval stages or (ii) "Direct" development of terrestrial eggs without larval stages.

Water_system: The water system in which species deposit their eggs, classified as (i) "Lotic" for species that breeds in flowing waters, such as rivers, streams, and rivulets; and (ii) "Lentic" water system for species breeding in still water like ponds and swamps. Species that reproduce in both water systems were classified as "Lentic_Lotic".

Eggs_Deposition: The substrate in which the species lay its eggs, classified as (i) "Water" for eggs laid directly in the flowing or still water; (ii) "Ground", when the eggs are laid directly on the ground, rocks or leaf on the ground; (iii) "Burrows", for eggs laid within a natural cavity or in a cavity built by the male or female of the species; (iv) "Basin", when eggs are laid in the water accumulated in a build basin nearby ponds, and (v) "Arboreal", eggs laid on leaves above the water system.

Nest: Some species use a foam nest to lay their eggs. We classified such species as "Foam". For the remaining species, we did not fill this field.

Reference_Breeding: References consulted for the breeding strategy of each species. All references are listed in Suppl. material 3. Personal Communication was provided directly by us or by other colleagues consulted.

\section{Taxonomy deliberation}

There are many taxonomy issues with amphibian species. Although taxonomists have improved their ability to unveil cryptic species, the cryptic diversity remains unknown in many tropical regions (Fouquet et al. 2007, Funk et al. 2012, Arteaga et al. 2016). Considering that some species in our dataset (Suppl. material 1: Table S1) are still unknown to science, we did not identify all occurrences at the species-level. For some occurrence records, we used confer ("cf.") to refer to species groups of either difficult identification based on preserved specimens or groups with high cryptic diversity. In the latter scenario, species would be distinguishable preferably through molecular analysis or bioacoustics parameters. For example, Elachistocleis matogrosso and E. bicolor, both occurring within UPRB, are diagnosed by the pattern of dorsal stripes (Caramaschi 2010). After specimen fixation and housing in museums, the efficacy of such diagnostic character is extremely reduced, which practically prevent the confirmation of species id based on preserved specimens 
only. That is also in the case with Adenomera species (Angulo et al. 2003). Species belonging to Adenomera and Elachistocleis were named as "cf." in Suppl. material 1: Table S1.

Because the collector has more tools to identify specimens alive during fieldwork (e.g., bioacoustics, color in life), we also included the original identification for all specimens classified as "cf." in the column "Id._Level" in Suppl. material 1: Table S1, with only two exemptions. First, we joined all specimens identified as Leptodactylus gracilis, L. jolyi, and L. sertanejo as Leptodactylus cf. jolyi, due to the high morphological similarity observed among preserved specimens of these species, besides their overlapping distributions (Neves et al. 2017).

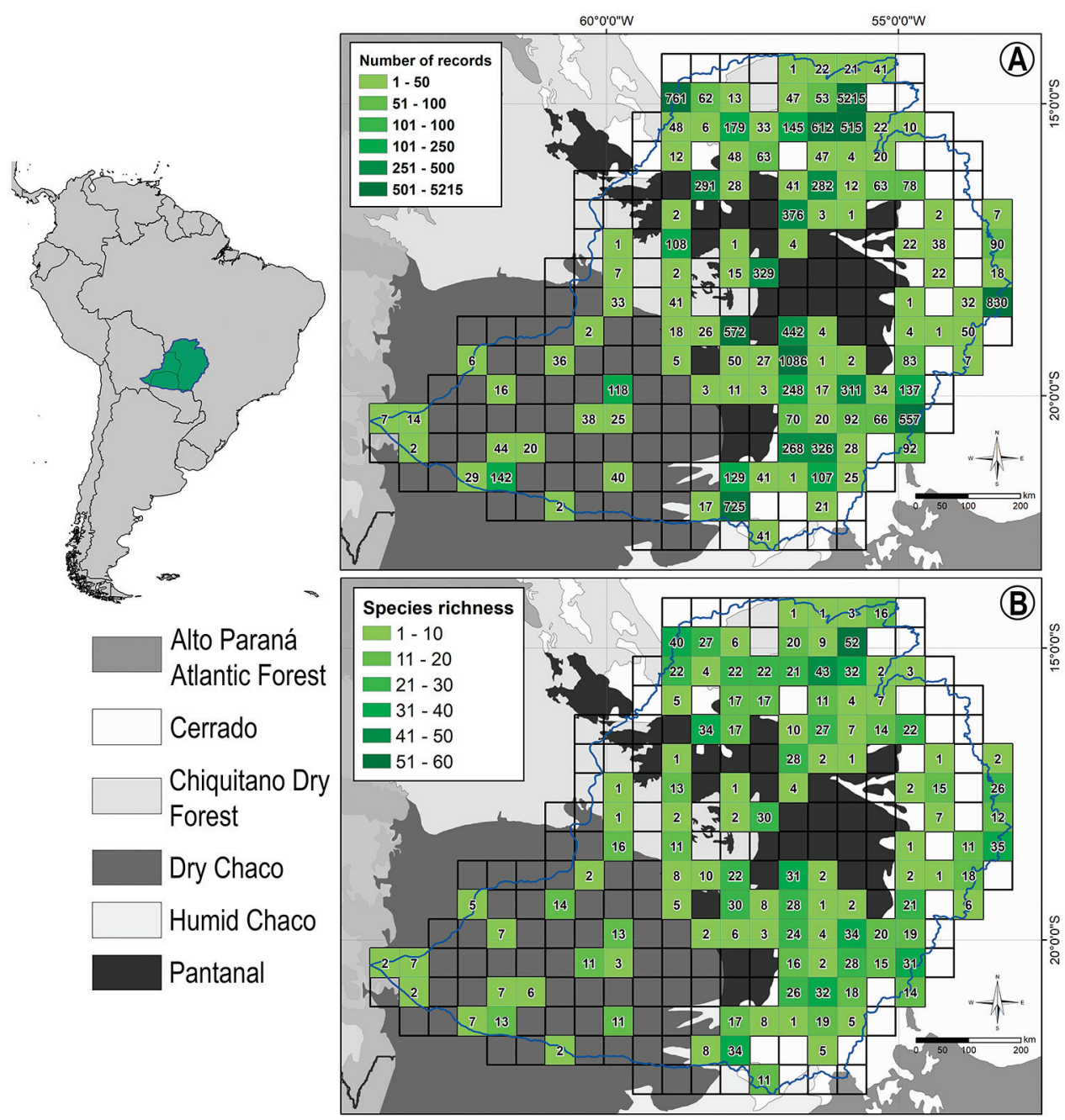

Figure I. The insertion of Upper Paraguay River Basin (UPRB) within South America. A Number of amphibian occurrence records and $\mathbf{B}$ number of amphibian species recorded within each quadrat within the UPRB. Quadrats were drawn at the spatial resolution of 0.5 decimal degree. Background layer shows ecoregions in grayscale (Olson et al. 2001). 
We also combined Pithecopus azureus and $P$. hypocondrialis under the name $P$. cf. hypocondrialis. Pithecopus azureus is distributed in the southern UPRB whereas $P$. hypocondrialis is an Amazonian species distributed in the northern UPRB (Frost 2020). However, the populations of $P$. cf. hypocondrialis found in the transitional zone of the distribution of these two species were not possible to identify using the diagnosis proposed by Caramaschi (2006). Therefore, we decided to place all the specimens as P. cf. hypocondrialis. In Suppl. material 2: Table S2, we provided the ecological traits for each species level named as "cf." in Suppl. material 1: Table S1. We also provide this information for $P$. azureus and $P$. hypochondrialis.
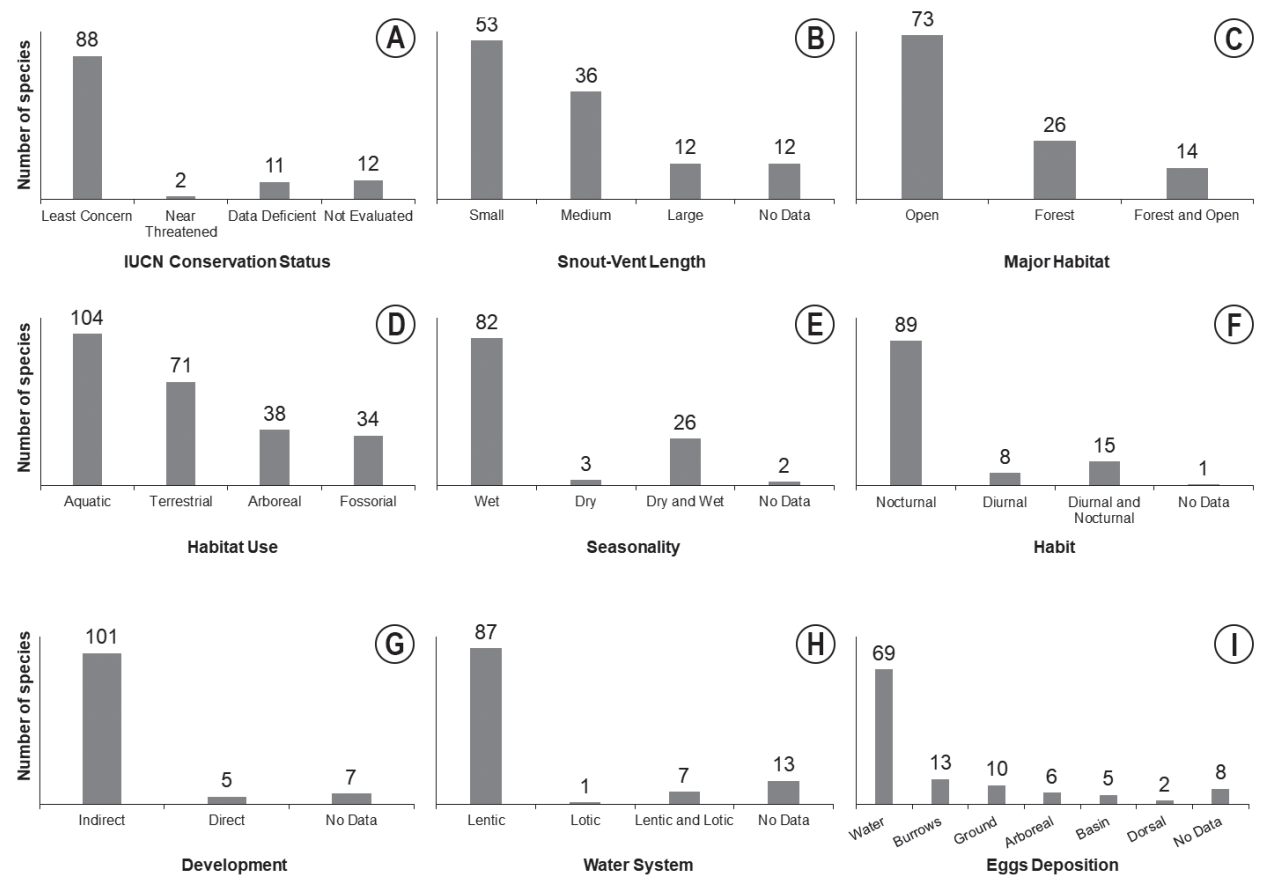

Figure 2. Species counting across levels of ecological traits for amphibians in Upper Paraguay River Basin. A Conservation status following International Union for Conservation of Nature and Natural Resources Red List of Threatened Species (2020) B body size category according to the snout-vent length (SVL) of each species. Categories correspond to row values (in millimeters - $\mathrm{mm}$ ) from SVL divided in Small $(0-39 \mathrm{~mm})$, Medium (40-79 mm), Large $(+80 \mathrm{~mm})$, and No Data when the SVL was not available in the literature $\mathbf{C}$ major Habitat where the species is more associated and it can be Open areas, Forest or both D habitat Use for each species as Aquatic, Arboreal, Fossorial and/or Terrestrial E the seasonality of species showing which are more active in the Wet, Dry or both season $\mathbf{F}$ habit of the species classified according to their period of activity, which may be diurnal, nocturnal or both $\mathbf{G}$ larval Development with species showing direct (without tadpole stage) or indirect (with tadpole) development $\mathbf{H}$ water system used by the species breeding in Lotic environment, Lentic or both; and I the surface of the Eggs Deposition of each species and it can be in Water, Burrows, Ground, Arboreal, Basin or on the specimen Dorsal region. A total of 108 species were used for Water System and Eggs Deposition due to the Direct Development species. 
For Odontophrynus species we kept the identification at the genus-level even knowing that two species within this genus occur in the UPRB $(O$. americanus and O. lavillai; Rosset and Baldo 2014). However, they are only distinguishable based on the ploidy of the cells or superficial characteristics, such as the pattern of dorsolateral spots (Rosset et al. 2006, 2009, Weiler et al. 2013), which makes their identification impossible with preserved species. Another issue concerns two Oreobates species that have their type localities within the UPRB. Oreobates crepitans was described from São Vicente, Cuiabá municipality, whereas $O$. heterodactylus was discovered in Cáceres municipality, both in Mato Grosso state, Brazil (Miranda-Ribeiro 1937, Bokermann 1965). However, the identity of these specimens in the collection is often unnamed and of difficult diagnosis based on specimens preserved (Padial et al. 2012). We thus placed Odontophrynus and Oreobates records as "sp." in Suppl. material 1: Table S1.

We use group ("gr.") for specimens from Scinax ruber and Dendropsophus parviceps species groups, for which we did not get the correct identification due to the high cryptic diversity among them. Other works have used the same nomenclature for both 'species group' in the literature (Kopp et al. 2010, São-Pedro and Feio 2010, Crivellari et al. 2014). Since the real identification of these species is untraceable, we removed them from Suppl. material 2: Table S2. The specimens named as Leptodactylus aff. natalensis is as yet an unknown species (Carvalho T., Personal communication).

\section{Preliminary analyses and directions for future research}

Datapapers compile well-curated species-level information on spatial and trait data of particular taxa and/or regions of interest (Chavan and Penev 2011). This datapaper comprises 17,089 records for 113 amphibian species, distributed in 14 families and 32 genera. Hylidae was the richest family (32 spp.) followed by Leptodactylidae (31 spp.), but this latter one showed the highest number of records (41.13\% of total occurrence records), followed by Hylidae (35.77\%). These two families are often the most common in short-term studies undertaken within the UPRB (e.g., Uetanabaro et al. 2007, 2008, Souza et al. 2010, 2017, Pansonato et al. 2011, Sugai et al. 2014).

The occurrence dataset is suitable to research on patterns of species diversity and distribution within UPRB (e.g., Valdujo et al. 2012, Roberto and Loebmann 2016, Silva et al. 2018). The regions with the highest number of species-occurrence records and apparent richness were concentrated in protected areas (e.g., Chapada dos Guimarães National Park, and Serra da Bodoquena National Park), target areas of environmental impact studies (e.g., Jauru and Manso hydroelectric plant regions), and around major urban centers (e.g., Campo Grande, Corumbá, and Cuiabá municipalities) (Suppl. material 1: Table S1; Fig. 1). Regions with striking sampling gaps or even without any species occurrence record are those showing low accessibility (e.g., Serra do Amolar, Pantanal do Paiaguás, and Pantanal do Nabileque). The Paraguayan portion of UPRB has a low number of records and only a few regions were sampled, nonetheless this may be biased due to the low number of Paraguayan scientific collections visited (Fig. 1B).

Species traits can greatly improve our understanding of ecological patterns and conservation planning (Grimm et al. 2014). Overall, species in the UPRB show prefer- 
ence for open habitats and aquatic microhabitat, with predominance of species mostly nocturnal that breed in the wet season (Suppl. material 2: Table S2). The most common breeding strategy was indirect development in lentic water, with eggs laid directly on the water (Fig. 2). It is worth noting the high frequency of missing data for several traits explored in Suppl. material 2: Table S2, even for species that are common and abundant in the Pantanal and surroundings (e.g. Boana lundii, Pseudis platensis, Scinax nasicus, Leptodactylus syphax). Our ecological trait dataset helps identify which ecological aspects of what species are less known and therefore deserve further investigations.

In summary, it is necessary to encourage researchers to make available their unpublished data in order to minimize our biodiversity knowledge gaps (Chavan and Penev 2011). Amphibians are a highly threatened vertebrate group and the UPRB harbors the world's largest tropical wetland area. We hope the present data paper facilitates studies on ecology and conservation of amphibians from the Pantanal and surrounding plateaus.

\section{Acknowledgments}

We thank the curators of the museums visited for support and allowing us to examine specimens in their care, and providing a database of records. MON and HC thank Coordenação de Aperfeiçoamento Pessoal de Nível Superior (CAPES) for a fellowship. HC would like to thank the Consejo Nacional de Ciencia y Tecnología (CONACYT), for financial support through the Programa Nacional de Incentivo a Investigadores (PRONII), and Programa de Estudantes-Convênio de Pós-Graduação (PEC-PG), for a fellowship. This work was funded by the Conselho Nacional de Desenvolvimento Científico e Tecnológico-CNPq through a research project and productivity fellowship for DJS (402519/2016-7 and 311492/2017-7) and VLF (409003/2018-2 and 309305/2018-7). Also, it was carried out with support from the Federal University of Mato Grosso do Sul - UFMS/MEC - Brazil

\section{References}

Alho CJR, Lacher Jr TE, Gonçalves HC (1988) Environmental degradation in the Pantanal ecosystem. Bioscience 38(3): 164-171. https://doi.org/10.2307/1310449

Angulo A, Cocroft RB, Reichle S (2003) Species identity in the genus Adenomera (Anura: Leptodactylidae) in Southeastern Peru. Herpetologica 59(4): 490-504. https://doi. org/10.1655/20-104

Arteaga A, Pyron RA, Peñafiel N, Romero-Barreto P, Culebras J, Bustamante L, Yánez-Muñoz MH, Guayasamin JM (2016) Comparative phylogeography reveals cryptic diversity and repeated patterns of cladogenesis for amphibians and reptiles in northwestern Ecuador. PLoS One 11(4): 1-40. https://doi.org/10.1371/journal.pone.0151746

Beck J, Böller M, Erhardt A, Schwanghart W (2014) Spatial bias in the GBIF database and its effect on modeling species' geographic distributions. Ecological Informatics 19: 10-15. https://doi.org/10.1016/j.ecoinf.2013.11.002 
Blonder B, Kapas RE, Dalton RM, Graae BJ, Heiling JM, Opedal ØH (2018) Microenvironment and functional-trait context dependence predict alpine plant community dynamics. Journal of Ecology 106(4): 1323-1337. https://doi.org/10.1111/1365-2745.12973

Bokermann WCA (1965) Tres novos batraquios da regiao central de Mato Grosso, Brasil (Amphibia, Salientia). Revista Brasileira de Biologia 25: 257-264.

Cadotte MW, Arnillas CA, Livingstone SW, Yasui SLE (2015) Predicting communities from functional traits. Trends in Ecology \& Evolution 30(9): 510-511. https://doi. org/10.1016/j.tree.2015.07.001

Caramaschi U (2006) Redefinição do grupo de Phyllomedusa hypochondrialis, com redescrição de P. megacephala (Miranda-Ribeiro, 1926), revalidação de P. azurea Cope, 1862 e descrição de uma nova espécie (Amphibia, Anura, Hylidae). Arquivos do Museu Nacional, Rio de Janeiro 64: 159-179.

Caramaschi U (2010) Notes on the taxonomic status of Elaschistocleis ovalis (Schneider, 1799) and description of five new species of Elachistocleis Parker, 1927 (Amphibia, Anura, Microhylidae). Boletim Do Museu Nacional. Nova Serie, Zoologia. Rio De Janeiro 527: 1-30.

Chavan V, Penev L (2011) The data paper: A mechanism to incentivize data publishing in biodiversity science. BMC Bioinformatics 12(S15, Suppl 1.): S2. https://doi.org/10.1186/14712105-12-S15-S2

Chen Y, Zhang J, Jiang J, Nielsen SE, He F (2017) Assessing the effectiveness of China's protected areas to conserve current and future amphibian diversity. Diversity \& Distributions 23(2): 146-157. https://doi.org/10.1111/ddi.12508

Collen B, Ram M, Zamin T, McRae L (2008) The tropical biodiversity data gap: Addressing disparity in global monitoring. Tropical Conservation Science 1(2): 75-88. https://doi. org/10.1177/194008290800100202

Coulthard E, Norrey J, Shortall C, Harris WE (2019) Ecological traits predict population changes in moths. Biological Conservation 233: 213-219. https://doi.org/10.1016/j.biocon.2019.02.023

Crivellari LB, Leivas PT, Leite JCM, Gonçalves DS, Mello CM, Rossa-Feres DC, Conte CE (2014) Amphibians of grasslands in the state of Paraná, southern Brazil (Campos Sulinos). Herpetology Notes 7: 639-654.

D’Amen M, Dubuis A, Fernandes RF, Pottier J, Pellissier L, Guisan A (2015) Using species richness and functional traits predictions to constrain assemblage predictions from stacked species distribution models. Journal of Biogeography 42(7): 1255-1266. https://doi. org/10.1111/jbi.12485

Diamond SE, Frame AM, Martin RA, Buckley LB (2011) Species' traits predict phenological responses to climate change in butterflies. Ecology 92(5): 1005-1012. https://doi. org/10.1890/10-1594.1

Dubuis A, Rossier L, Pottier J, Pellissier L, Vittoz P, Guisan A (2013) Predicting current and future spatial community patterns of plant functional traits. Ecography 36(11): 1158-1168. https://doi.org/10.1111/j.1600-0587.2013.00237.x

Foden WB, Butchart SHM, Stuart SN, Vié JC, Akçakaya HR, Angulo A, DeVantier LM, Gutsche A, Turak E, Cao L, Donner SD, Katariya V, Bernard R, Holland RA, Hughes AF, O’Hanlon SE, Garnett ST, Şekercioğlu ÇH, Mace GM (2013) Identifying the 
world's most climate change vulnerable species: A systematic trait-based assessment of all birds, amphibians and corals. PLoS One 8(6): e65427. https://doi.org/10.1371/journal. pone.0065427

Fouquet A, Vences M, Salducci MD, Meyer A, Marty C, Blanc M, Gilles A (2007) Revealing cryptic diversity using molecular phylogenetics and phylogeography in frogs of the Scinax ruber and Rhinella margaritifera species groups. Molecular Phylogenetics and Evolution 43(2): 567-582. https://doi.org/10.1016/j.ympev.2006.12.006

Frost DR (2020) Amphibian Species of the World: an Online Reference. http://research.amnh. org/herpetology/amphibia/index.html

Funk WC, Caminer M, Ron SR (2012) High levels of cryptic species diversity uncovered in Amazonian frogs. Proceedings. Biological Sciences 279(1734): 1806-1814. https://doi. org/10.1098/rspb.2011.1653

GBIF.org (2019) GBIF Home Page. http://www.gbif.org

Gillings S, Balmer DE, Caffrey BJ, Downie IS, Gibbons DW, Lack PC, Reid JB, Sharrock JTR, Swann RL, Fuller RJ (2019) Breeding and wintering bird distributions in Britain and Ireland from citizen science bird atlases. Global Ecology and Biogeography: 1-9. https:// doi.org/10.1111/geb.12906

Grimm A, Ramírez AMP, Moulherat S, Reynaud J, Henle K (2014) Life-history trait database of European reptile species. Nature Conservation 9: 45-67. https://doi.org/10.3897/natureconservation.9.8908

Guisan A, Mod HK, Scherrer D, Münkemüller T, Pottier J, Alexander JM, D’Amen M (2019) Scaling the linkage between environmental niches and functional traits for improved spatial predictions of biological communities. Global Ecology and Biogeography : 1-9. https://doi. org/10.1111/geb.12967

Haddad CFB, Prado CPA (2005) Reproductive modes of the Atlantic Forest frogs. Bioscience 55: 208-217. https://doi.org/10.1641/0006-3568(2005)055[0207:RMIFAT]2.0.CO;2

Holt RD (2003) On the evolutionary ecology of species' ranges. Evolutionary Ecology Research 5: 159-178.

Hopkins MJG (2007) Modelling the known and unknown plant biodiversity of the Amazon Basin. Journal of Biogeography 34(8): 1400-1411. https://doi.org/10.1111/j.13652699.2007.01737.x

Ingram T, Shurin JB (2009) Trait-based assembly and phylogenetic structure in northeast Pacific rockfish assemblages. Ecology 90(9): 2444-2453. https://doi.org/10.1890/08-1841.1

IUCN (2020) The IUCN Red List of Threatened Species. https://www.iucnredlist.org

Junk WJ, Wantzen KM (2004) The flood pulse concept: new aspects, approaches, and applications - an update. In: Welcomme RL, Petr T (Eds) Proceedings of the Second International Symposium on the Management of Large Rivers for Fisheries, Volume 2. Food and Agriculture Organization \& Mekong River Commission. FAO Regional Office for Asia and the Pacific, Bangkok, 117-149.

Kopp K, Signorelli L, Bastos RP (2010) Distribuição temporal e diversidade de modos reprodutivos de anfíbios anuros no Parque Nacional das Emas e Entorno, estado de Goiás, Brasil. Iheringia. Série Zoologia 100(3): 192-200. https://doi.org/10.1590/S007347212010000300002 
Lips KR, Reeve JD, Witters LR (2003) Ecological traits predicting amphibian population declines in Central America. Conservation Biology 17(4): 1078-1088. https://doi. org/10.1046/j.1523-1739.2003.01623.x

Lomolino MV (2004) Conservation Biogeography. In: Lomolino MV, Heaney LR (Eds) Frontiers of biogeography. New directions in the geography of nature. Sinauer Associates, Sunderland, 293-296.

Lomolino MV, Riddle BR, Whittaker RJ (2016) Biogeography. $5^{\text {th }}$ ed. Oxford University Press, Oxford, 730 pp.

Meyer C (2016) Limitations in global information on species occurrences. Frontiers of Biogeography 8(2): 1-7. https://doi.org/10.21425/F5FBG28195

Meyer C, Jetz W, Guralnick RP, Fritz SA, Kreft H (2016) Range geometry and socio-economics dominate species-level biases in occurrence information. Global Ecology and Biogeography 25(10): 1181-1193. https://doi.org/10.1111/geb.12483

Miranda-Ribeiro A (1937) Alguns batrachios novos das colleçcóes do Museo Nacional. O Campo. Rio de Janeiro 8: 66-69.

Moura MR, Costa HC, Peixoto MA, Carvalho ALG, Santana DJ, Vasconcelos HL (2018) Geographical and socioeconomic determinants of species discovery trends in a biodiversity hotspot. Biological Conservation 220: 237-244. https://doi.org/10.1016/j.biocon.2018.01.024

Neves MO, Pereira EA, Lima LMC, Folly H, De Oliveira EF, Santana DJ, Feio RN (2017) Anurans of Serra Negra da Mantiqueira, Zona da Mata of Minas Gerais, Brazil: A priority area for biodiversity conservation. Herpetology Notes 10: 297-311.

Oliveira BF, São-Pedro VA, Santos-Barrera G, Penone C, Costa GC (2017) AmphiBIO, a global database for amphibian ecological traits. Scientific Data 4(1): 1-7. https://doi. org/10.1038/sdata.2017.123

Olson DM, Dinerstein E, Wikramanayake ED, Burgess ND, Powell GVN, Underwood EC, D'amico JA, Itoua I, Strand HE, Morrison JC, Loucks CJ, Allnutt TF, Ricketts TH, Kura Y, Lamoreux JF, Wettengel WW, Hedao P, Kassem KR (2001) Terrestrial ecoregions of the world: A new map of life on Earth. Bioscience 51(11): 933. https://doi.org/10.1641/00063568(2001)051[0933:TEOTWA]2.0.CO;2

Padial JM, Chaparro JC, Castroviejo-Fisher S, Guayasamin JM, Lehr E, Delgado AJ, Vaira M, Teixeira M, Aguayo R, De la Riva I (2012) A revision of species diversity in the Neotropical genus Oreobates (Anura: Strabomantidae), with the description of three new species from the Amazonian slopes of the Andes. American Museum Novitates 3752(3752): 1-55. https://doi.org/10.1206/3752.2

Pansonato A, Mott T, Strüssmann C (2011) Anuran amphibians' diversity in a northwestern area of the Brazilian Pantanal. Biota Neotropica 11(4): 77-86. https://doi.org/10.1590/ S1676-06032011000400008

Piatti L, Rosauer DF, Nogueira CC, Strüssmann C, Ferreira VL, Martins M (2019) Snake diversity in floodplains of central South America: Is flood pulse the principal driver? Acta Oecologica 97: 34-41. https://doi.org/10.1016/j.actao.2019.04.003

Roberto IJ, Loebmann D (2016) Composition, distribution patterns, and conservation priority areas for the herpetofauna of the state of Ceará, northeastern Brazil. Salamandra (Frankfurt) 52: 134-152. 
Rosset S, Baldo D (2014) The advertisement call and geographic distribution of Odontophrynus lavillai Cei, 1985 (Anura: Odontophrynidae). Zootaxa 3784(1): 79-83. https://doi. org/10.11646/zootaxa.3784.1.5

Rosset SD, Baldo D, Lanzone C, Basso NG (2006) Review of the geographic distribution of diploid and tetraploid populations of the Odontophrynus americanus species complex (Anura: Leptodactylidae). Journal of Herpetology 40(4): 465-477. https://doi.org/10.1670/00221511(2006)40[465:ROTGDO]2.0.CO;2

Rosset SD, Baldo D, Haddad CFB (2009) Amphibia, Anura, Cycloramphidae, Odontophrynus lavillai: First record for Brazil and geographic distribution map. Check List 5(1): 32-34. https://doi.org/10.15560/5.1.32

São-Pedro VA, Feio RN (2010) Distribuição espacial e sazonal de anuros em três ambientes na Serra do Ouro Branco, extremo sul da Cadeia do Espinhaço, Minas Gerais, Brasil. Biotemas 23: 143-154. https://doi.org/10.5007/2175-7925.2010v23n1p143

Silva MP, Mauro R, Mourão G, Coutinho M (2000) Distribuição e quantificação de classes de vegetação do Pantanal através de levantamento aéreo. Revista Brasileira de Botanica. Brazilian Journal of Botany 23(2): 143-152. https://doi.org/10.1590/S010084042000000200004

Silva ET, Peixoto MAA, Leite FSF, Feio RN, Garcia PCA (2018) Anuran distribution in a highly diverse region of the Atlantic Forest: The Mantiqueira Mountain Range in Southeastern Brazil. Herpetologica 74(4): 294-305. https://doi.org/10.1655/HerpetologicaD-17-00025.1

Souza FL, Uetanabaro M, Landgref-Filho P, Piatti L, Prado CPA (2010) Herpetofauna, municipality of Porto Murtinho, Chaco region, state of Mato Grosso do Sul, Brazil. Check List 6(3): 470-475. https://doi.org/10.15560/6.3.470

Souza FL, Prado CPA, Sugai JLMM, Ferreira VL, Aoki C, Landgref-Filho P, Strüssmann C, Ávila RW, Rodrigues DJ, Albuquerque NR, Terra J, Uetanabaro M, Béda AF, Piatti L, Kawashita-Ribeiro RA, Delatorre M, Faggioni GP, Demczuk SDB, Duleba S (2017) Diversidade de anfíbios do Estado de Mato Grosso do Sul, Brasil. Iheringia. Série Zoologia 107(suppl): 1-10. https://doi.org/10.1590/1678-4766e2017152

Sugai JLMM, Terra J de S, Ferreira VL (2014) Anurans of a threatened savanna area in western Brazil. Biota Neotropica 14(1). https://doi.org/10.1590/S1676-06034058

Swenson NG, Weiser MD (2010) Plant geography upon the basis of functional traits: An example from eastern North American trees. Ecology 91(8): 2234-2241. https://doi. org/10.1890/09-1743.1

Troudet J, Grandcolas P, Blin A, Vignes-Lebbe R, Legendre F (2017) Taxonomic bias in biodiversity data and societal preferences. Scientific Reports 7(1): 1-14. https://doi.org/10.1038/ s41598-017-09084-6

Uetanabaro M, Souza FL, Landgref-Filho P, Beda AF, Brandão RA (2007) Amphibians and reptiles of the Serra da Bodoquena National Park, Mato Grosso do Sul, central Brazil. Biota Neotropica 7: 279-289. https://doi.org/10.1590/S1676-06032007000300030

Uetanabaro M, Prado CPA, Rodrigues DDJ, Gordo M, Campos Z (2008) Guia de Campo de Anuros do Pantanal Sul e Planaltos de Entorno. Editora UFMS/UFMT, Campo Grande, 196 pp.

UNESCO (2020) World Heritage List. http://whc.unesco.org/en/list/ 
Valdujo PH, Silvano DL, Colli G, Martins M (2012) Anuran species composition and distribution patterns in Brazilian Cerrado, a Neotropical Hotspot. South American Journal of Herpetology 7(2): 63-78. https://doi.org/10.2994/057.007.0209

Weiler A, Nuñez K, Airaldi K, Lavilla E, Peris S, Baldo D (2013) Anfibios del Paraguay, 132 pp. Wells KD (2007) The Ecology and Behavior of Amphibians. University of Chicago Press, 1148 pp. https://doi.org/10.7208/chicago/9780226893334.001.0001

Whittaker RJ, Araújo MB, Jepson P, Ladle RJ, Watson JEM, Willis KJ (2005) Conservation biogeography: Assessment and prospect. Diversity \& Distributions 11(1): 3-23. https:// doi.org/10.1111/j.1366-9516.2005.00143.x

Williams NM, Crone EE, Roulston TH, Minckley RL, Packer L, Potts SG (2010) Ecological and life-history traits predict bee species responses to environmental disturbances. Biological Conservation 143(10): 2280-2291. https://doi.org/10.1016/j.biocon.2010.03.024

\section{Supplementary material I}

\section{Table S1}

Authors: Matheus Oliveira Neves, Hugo Cabral, Mariana Pedrozo, Vanda Lucia Ferreira, Mário Ribeiro Moura, Diego José Santana

Data type: Species occurrence data

Explanation note: Data on occurrence records containing the collection of housing, locality, geographical coordinates, geographic accuracy, collection date, and collector name. Copyright notice: This dataset is made available under the Open Database License (http://opendatacommons.org/licenses/odbl/1.0/). The Open Database License $(\mathrm{ODbL})$ is a license agreement intended to allow users to freely share, modify, and use this Dataset while maintaining this same freedom for others, provided that the original source and author(s) are credited.

Link: https://doi.org/10.3897/natureconservation.41.54265.suppl1

\section{Supplementary material 2}

\section{Table S2}

Authors: Matheus Oliveira Neves, Hugo Cabral, Mariana Pedrozo, Vanda Lucia Ferreira, Mário Ribeiro Moura, Diego José Santana

Data type: Species-level trait data

Explanation note: Data on ecological traits for each species, including morphometry, diet, activity pattern, habitat use, and breeding strategy.

Copyright notice: This dataset is made available under the Open Database License (http://opendatacommons.org/licenses/odbl/1.0/). The Open Database License $(\mathrm{ODbL})$ is a license agreement intended to allow users to freely share, modify, and use this Dataset while maintaining this same freedom for others, provided that the original source and author(s) are credited.

Link: https://doi.org/10.3897/natureconservation.41.54265.suppl2 


\section{Supplementary material 3}

\section{References from the citations contained in Suppl. material 2}

Authors: Matheus Oliveira Neves, Hugo Cabral, Mariana Pedrozo, Vanda Lucia Ferreira, Mário Ribeiro Moura, Diego José Santana

Data type: References

Copyright notice: This dataset is made available under the Open Database License (http://opendatacommons.org/licenses/odbl/1.0/). The Open Database License $(\mathrm{ODbL})$ is a license agreement intended to allow users to freely share, modify, and use this Dataset while maintaining this same freedom for others, provided that the original source and author(s) are credited.

Link: https://doi.org/10.3897/natureconservation.41.54265.suppl3 